Arta Snipe, LL. M.

University of Latvia, Latvia

\title{
AMOUNT OF THE LEASE FEE IN THE COMPULSORY LAND LEASE RELATIONS
}

\section{NOMAS MAKSAS APMĒRS ZEMES PIESPIEDU NOMAS ATTIECĪBĀS}

\begin{abstract}
Kopsavilkums
Nomas maksas apmēru zemes piespiedu nomas tiesiskajās attiecībās ietekmē juridiski, ekonomiski un politiski apsvērumi. Kad zemes nodevu nosaka likums, dominē politiski apsvērumi. Kad tiesa nosaka nomas maksu, prevalē juridiski apsvērumi, bet, noslēdzot līgumu, dominē ekonomiski apsvērumi. Izmantojot ikvienu no metodēm, noteiktā optimālā nomas maksas summa tik ḷoti atškịas, ka nav iespējams panākt kompromisu. Vienīgais risinājums, kurā ievērotas zemes īpašnieku un ēku īpašnieku konstitucionālās tiesības, ir škirto īpašumtiesību apvienošana.
\end{abstract}

Atslēgvārdi: zemes piespiedu noma, nomas maksas apmērs, taisnīga atlīdzība

\begin{abstract}
Summary
The lease fee amount in compulsory land lease relations is affected by legal, economic and political considerations. When the fee is defined by the law, political considerations dominate. When the court determines the fee, legal considerations prevail, but when a contract is concluded, economic considerations prevail. The optimal lease fee amount determined under each of the methods gives results so different that it is impossible to reach a compromise. The only solution that respects the constitutional right of landowners and building owners is the unification of separated ownership.
\end{abstract}

Keywords: compulsory land lease, lease fee amount, fair compensation

\section{Introduction}

When independence of Latvia was proclaimed in 1990, it was decided to restore the ownership rights of the properties nationalized since 1940 to the former owners (or their heirs), rather than paying them a compensation. In the cases, where the ownership rights were restored to land on which apartment houses were built during the Soviet times, a situation arose whereby the land and the buildings on it had different owners. In 2015, in Latvia there were 285549 buildings located on 95254 land lots, owned by other parties than the owners of respective buildings. 3677 of those were apartment houses (totaling 110970 apartments) located on 7354 land lots.

The relationships between landowners and owners of buildings are regulated as lease agreements, whereby the maximum amount of lease fee is limited by law. The constitutionality of the lease fee amount since 2007 has been considered by the Constitutional Court several times already. In 2019, the Ministry of Justice prepares a new 
draft law to transform the relations of compulsory land lease into statutory usufructs. Still, the most controversial issue is the fee amount the owners of buildings must pay to the landowners.

\section{The lease fee amount}

The amount of the land lease fee has been regulated since the establishment of compulsory land lease in the beginning of the 1990s. ${ }^{1}$ The legislature set the maximum fee for a number of properties. ${ }^{2}$ Since year 1995, both the law "On land reform in the cities of the Republic of Latvia" and the law "On privatization of state and municipal residential houses" set that the lease fee in the cases provided by law may not be higher than $5 \%$ per year from the cadastral value of the land. This fee limit was based on trends in the case law in the mid-1990s. ${ }^{3}$ Only in 2010 the lease fee was set to $6 \%$ per year from the cadastral value of the land if the parties have not agreed otherwise.

Initially it was meant as a transitional solution to determine the fee limit in the law. ${ }^{4}$ However, regulatory prices in this field are still relevant. In a free market, the equilibrium price of the lease is determined by demand and supply. In the situation with separated ownership of property, there is no competition, none of the parties has the option of choosing another contractor. Under these circumstances, the state intervention in determining the fair compensation (lease fee) is acceptable and even necessary.

The amount of the lease fee is stipulated by law in special cases, namely, when on the land there is a residential building or an apartment building, or objects of public interest. ${ }^{5}$ In other cases, if the parties have not reached an agreement on the fee, it is determined by the court in accordance with Articles 2122, 2120, 2017, 2018, 2019 and 5 of the Civil Law of the Republic of Latvia.

The lease fee amount is affected by legal, economic and political considerations. When the lease fee is defined by law, dominant are political considerations. When the court determines the lease fee in the event of a dispute, legal considerations prevail, but upon agreement between the parties the economic considerations prevail.

1 Judgement of 15 April 2009 by the Constitutional Court of the Republic of Latvia in case No. 200836-01. Latvijas Vēstnesis, 2009. 21. aprïlis, Nr. 60 (4046), para. 15.1.

2 Par zemes reformu Latvijas Republikas pilsētās: LV Likums [Law "On Land Reform in Cities of the Republic of Latvia"]. Ziṇotājs, 1991. 19. decembris, Nr. 49/50, Sec. 12 (3); Par zemes nomas maksas maksimālo lielumu Latvijas Republikas pilsētās: Ministru Padomes lēmums Nr. 243. [Decision No 243 of the Council of Ministers "On the maximal amount of the lease fee in the cities of the Republic of Latvia]. Latvijas Vēstnesis, 1993. 15. maijs, Nr. 25.

3 Judgement of 15 April 2009 by the Constitutional Court of the Republic of Latvia in case No. 2008-36-01, para. 15.2.

4 Saeimas Valsts pārvaldes un pašvaldỉbas komisija. Anotation to the draft law "Piespiedu dalitā īpašuma privatizētajās daudzdzīvokḷu mājās izbeigšanas likums” (Nr. 1211/Lp12). [Public Administration and Local Government Committee of the Saeima of the Republic of Latvia, annotation to the draft law "Law on Terminating the Enforced Separated Ownership in the Privatised Multi-apartment Buildings" (No. 1211/Lp12)]. Available at: http://titania.saeima.lv/LIVS12/saeimalivs12.nsf/0/5986C97B 49BD24A3C225826D004B1314 [last viewed July 30, 2018].

5 Par zemes reformu Latvijas Republikas pilsētas: LV Likums [law "On Land Reform in Cities of the Republic of Latvia”]. Ziṇotājs, 1991. 19. decembris, Nr. 49/50, Sec. 12 (2)(3). 


\section{Political aspect}

The presence of the political aspect in the legislation process means the influence of political and social situation, public values, political course of the state. The concepts of "socially responsible state" or "support for free market economy" are political considerations, as the legislature creates the laws in accordance with these ideas and aims.

Establishment of separated ownership of property in the course of land reform was a political decision. Although the rules governing the amount of the lease fee theoretically are designed to strike a fair balance between the interests of landowners and building owners, ${ }^{6}$ the actual aim of these norms has always been to protect building owners from high maintenance costs. ${ }^{7}$

This was reflected in the amendments adopted shortly before the municipal elections in 2017. The amendments reduced landowners' gross income at least twice, reducing the net income at least three times, and decreasing the payments for the voters supposedly living in more than 100000 apartments. ${ }^{8}$ The parliament ignored the opinion of the Legal Bureau of the Saeima on the likely non-compliance of the regulation with the constitution. ${ }^{9}$ The political goals and the political considerations overrode the legal considerations. The political aims were probably met, as the candidates, who used these amendments in their individual election campaigns, got extra 'plus' points and secured their place in the City Council of Riga. ${ }^{10}$

\section{Legal aspect}

When the legislature's decisions become too politically influenced or even populistic, they are controlled by other branches of state power. Actions of legislature must

6 Judgement of 15 April 2009 by the Constitutional Court of the Republic of Latvia in case No. 200836-01. Latvijas Vēstnesis, 2009. 21. aprīlis, Nr. 60 (4046), para. 4.

7 Judgement of 15 April 2009 by the Constitutional Court of the Republic of Latvia in case No. 200836-01., paras 12.1, 12.2; Judgement of 27 January 2011 by the Constitutional Court of the Republic of Latvia in case No. 2010-22-01. Latvijas Vēstnesis, 2011. 1. februāris, Nr. 17 (4415), para. 12.3., Judgement of 12 April 2018 by the Constitutional Court of the Republic of Latvia in case No. 201717-01. Latvijas Vēstnesis. 2018. 13 aprïlis, Nr. 74 (6160), paras 5, 7.

8 Latvijas Republikas 12. Saeimas deputāts A. Elksniņš. Proposals to the draft law "Grozijumi likumā "Par valsts un pašvaldỉbu dzīojamo māju privatizāciju" (446/Lp12). [Member of the 12th Saeima of the Republic of Latvia A.Elksniņš. Proposals to the draft law "Amendments to the law "On Privatisation of State and Local Government Residential Houses" (446/Lp12).] Available at: http://titania.saeima. lv/LIVS12/SaeimaLIVS12.nsf/0/11A87AA271C6FF49C2257F9B0044CE84? [last viewed August $16,2018]$.

9 Latvijas Republikas Saeimas Juridiskais birojs. [Legal Bureau of the Saeima of the Republic of Latvia]. Opinion on a draft law Nr. 446/Lp12. Available at: http://titania.saeima.lv/LIVS12/SaeimaLIVS12. nsf/0/F5DA04880A59C96DC2258128004D50E1 [last viewed August 16, 2018].

10 Note: The union between parties "Saskaņa" and "Gods kalpot Rigai", whose representatives promoted, supported and used the issue in the pre-election campaign, together received $50.82 \%$ of the votes in Riga. In her private campaign, compulsory land lease issues on social networks were accentuated and used by candidate Regina Ločmele-Luñova, gaining great recognition and 14802 'pros' from 127099 votes "Saskaņa" received altogether (i.e., at least every tenth voter supported her candidacy). 
comply with the norms of the Satversme and general principles of law. ${ }^{11}$ This is ensured by the Constitutional Court, who guarantees the balance between the rights and interests of the persons involved.

The Constitutional Court assesses the amount of the lease fee from the legal perspective. It has assessed the constitutionality of the lease fee already three times. The first time was in 2008, when the cadastral value was updated, and it grew rapidly. Since the lease fee is set as a percentage of the cadastral value, to protect the owners of buildings from the increasing fees, the law introduced a restriction on the increase in lease fee amount. The legal provisions were copied from the Law on Real Estate Tax, providing for the gradual increase in the amount of tax, without calculations regarding the lease fee.

In case No. 2008-36-01, the Constitutional Court concluded that the criterion of proportionality was not met and emphasized the duty of the legislator to establish a fair balance between the interests of landowners and apartment owners. ${ }^{12}$ It stated that the maximum amount of lease fee set in the law (5\%) cannot be regarded as fulfilling the remuneration function. ${ }^{13}$ The Court gave the legislator time until 1 November 2009 to draft a new regulation. Shortly before this deadline, the Saeima, "in order to ensure compliance with the legal interests of privatized apartment owners" and with the aim of "eliminating a situation that would allow landowners to gain disproportionate profits", repeatedly adopted identical provisions, without any economic justification. ${ }^{14}$ In the absence of any calculations, the Constitutional Court in case No. 2010-22-01 once again found that the norms did not comply with the proportionality criterion. ${ }^{15}$

A similar decision was made by the Constitutional Court in year 2018, when in the case No. 2017-17-01 the amendments made by the Saeima before the municipal elections were assessed. With these amendments, the maximum lease fee set in the law was gradually, but significantly reduced (from $6 \%$ to $3 \%$ of the cadastral value of the land lot per year). The Constitutional Court again found the fee limitations unconstitutional, since prior to adopting the contested norms the legislator had not carried out a due analysis on the lease fee amount. ${ }^{16}$

\section{Economic aspect}

The legal criteria for determining the amount of lease fee are included in the Civil Law. They, inter alia, stipulate that the lease fee must be fair compensation for

11 Judgement of 12 April 2018 by the Constitutional Court of the Republic of Latvia in case No. 201717-01, para. 21.3.

12 Judgement of 15 April 2009 by the Constitutional Court of the Republic of Latvia in case No. 200836-01, para. 16.

13 Ibid., para. 15.1.

14 Judgement of 27 January 2011 by the Constitutional Court of the Republic of Latvia in case No. 2010-22-01. Latvijas Vēstnesis, 2011. 1. februāris, Nr. 17 (4415), para. 13.

15 Ibid., paras 13.1-13.4.

16 Judgement of 12 April 2018 by the Constitutional Court of the Republic of Latvia in case No. 2017$17-01$, paras 21.3, 22.3. 
the use of the property (Art. 2120). The amount of fair compensation can only be calculated economically. When parties cannot agree on the fee amount, the Civil Law provides the criteria: the market price or average price at the time and place of contract. However, in case of compulsory land lease the reference to market price is useless, as market prices exist only in free market. Similarly, price comparison with voluntary right of superficies agreements is unfounded.

The economic aspect of the lease fee has not been assessed in legislation process. There is no clear and indisputable methodology to follow. However, as the optimal lease fee should be a fair renumeration, then it is appropriate to apply economic models and economic indicators that are used to determine the return from the property.

\section{Definitions of terms and assumptions used in the analysis}

Economists talk about lease fee amounts in the terms of potential income from investment. The analysis uses following economic terms:

- Net operating income (NOI) - the income received from the property. ${ }^{17}$ It is calculated as estimated lease minus the expenses (property taxes, expenses for collection of the lease and legal fees). Usually VAT is not included in the calculation of NOI, but the latest case law stipulates that it should be included in the maximum amount of the fee set in the law. ${ }^{18}$

- Capitalization rate or cap rate $(\mathrm{R})$ indicates the rate of return that is expected to be generated. Most commonly, cap rate is the ratio of the net income to the value of the property. ${ }^{19}$ a lower cap rate corresponds to a lower level of risk, while a higher cap rate implies more risk. It also depends on the location and the type of property. a cap rate that falls between 4 percent and 10 percent is typical and considered to be a good cap rate for investment in real estate. ${ }^{20}$

- Discount rate $(r)$ is the rate of return that investors require to invest in a property. The rate depends on the riskiness. ${ }^{21}$

- Value of the land (V). For the purpose of the analysis it is assumed that the value of the property is the same as the cadastral value.

- Beta (B) is a coefficient, which can estimate the risk associated with a specific industry, the volatility compared to the overall market.

17 Brueggeman W. B., Fisher J. D. Real estate finance and investments. $10^{\text {th }}$ ed. New York: McGraw-Hill Irwin, 1997, p. 239.

18 Judgement of 9 April 2019 by the Senate of the Republic of Latvia in case No. SKC-42/2019.

19 Brueggeman, ibid., p. 256.

20 Bethell A. Capitalization Rate Formula \& What a Good Cap Rate Is. Available at: https:// fitsmallbusiness.com/capitalization-rate-formula/ [last viewed April 17, 2019].

21 Brueggeman, ibid., p. 255. 


\section{Calculation of cap rate}

Cap rate can be calculated in several ways:

(1) As the ratio of net income to the value of the property $(\mathrm{R}=\mathrm{NOI} / \mathrm{V})$.

(2) By summing up the potential risks of the specific investment. ${ }^{22}$

(3) As a difference between the discount rate and the expected growth in income..$^{23}$

Actual cap rate calculated as per formula (1) according to the provisions in force in years $2017-2019(6 \%, 5 \%, 4 \%$ of cadastral value) and initiated in the amendments (3\%) can be seen in Table 1 .

\begin{tabular}{cccccccc}
$\begin{array}{c}\text { Value }(\mathrm{V})= \\
\text { cadaster value }^{1}\end{array}$ & $\begin{array}{c}\text { Lease fee } \\
(\mathrm{L})\end{array}$ & $\begin{array}{c}\text { property tax }- \\
1,5 \% \cdot \mathrm{V} \\
(\mathrm{NIN})\end{array}$ & $\begin{array}{c}\text { expenses } \\
(\exp ) \\
\mathrm{L} \cdot 7.5 \%^{2}\end{array}$ & $\begin{array}{c}\mathrm{VAT} \\
(21 \% \cdot \\
(\mathrm{L}-\mathrm{VAT}))\end{array}$ & $\begin{array}{c}\text { Irrecoverable } \\
\text { debts } \\
(5 \% \cdot \mathrm{L})\end{array}$ & $\begin{array}{c}\text { NOI }= \\
\text { L-NIN-exp- } \\
\text { VAT }\end{array}$ & $\mathrm{R}=\mathrm{NOI} / \mathrm{V}$ \\
\hline 100 & 6 & -1.5 & -0.45 & -1.04 & -0.3 & 2.71 & $2.7 \%$ \\
100 & 5 & -1.5 & -0.38 & -0.87 & -0.25 & 2.01 & $2.0 \%$ \\
100 & 4 & -1.5 & -0.3 & -0.69 & -0.2 & 1.31 & $1.3 \%$ \\
100 & 3 & -1.5 & -0.23 & -0.52 & -0.15 & 0.60 & $0.6 \%$
\end{tabular}

1 It is assumed the value of the property is 100 "units".

2 Lease collection expenses are estimated as $7.5 \%$ of the lease fee, as the average of $5 \%$ mentioned in the literature as minimal cost for payment collection and $10 \%$ commission rate applied by most house managers who offer this service in Latvia

Cap rate calculated as per formulas (2) and (3) can be used to determine the optimal lease fee to provide a fair income from the property.

The cap rate used in real estate appraisal usually consists of several components, all of which are summed:

- Risk-free rate $(0.8-1.2 \%){ }^{24}$

- Risk premium for investing in encumbered real estate $\left(1.67 \% \%^{25} \cdot 1.35^{26}+2 \%\right)$. Risk premium is estimated from country and investment field risk premiums plus the premium of legislation risk is added. As the legislation changes every

22 Brueggeman, ibid., p. 326.

23 Ibid., p. 290.

${ }^{24}$ Annual secondary market yields of government bonds with maturities of close to ten years. See: European Central Bank. Long-term interest rate statistics for EU Member States. Available at: https:// www.ecb.europa.eu/stats/financial_markets_and_interest_rates/long_term_interest_rates/html/ index.en.html [last viewed April 17, 2019].

25 Country risk premium. See: Damoran A. Country Default Spreads and Risk Premiums. Available at: http://pages.stern.nyu.edu/ adamodar/New_Home_Page/datafile/ctryprem.html [last viewed April 17, 2019].

26 Unlevered beta for real estate investments in Latvia, small companies. See: WaccExpert. Data for Latvia, real estate sector. Available at: http://www.waccexpert.com/?country=1730\&sector= 147\&detailledView=true [last viewed April 17, 2019]. 
few years, it is difficult to make any long-term assumptions, thus cap rates rise considerably.

- Property management expenses $(2 \%)$. These include taxes and fee collection expenses. a specific risk that increases the cap rate are irrecoverable debts. ${ }^{27}$

- Liquidity premium, i.e. compensation for lower liquidity compared to a deposit in a bank or other securities (at least $2 \%$ )

Thus, optimal cap rate as per formula (2) is between $6.2 \%-7 \%$.

Methodology for calculating the discount rate for the state regulated sectors, which can be used as an example in cases of separated ownership, ${ }^{28}$ has been prepared by the Public Utilities Commission. ${ }^{29}$ The discount rate consists of two components: risk-free rate $(0.8-1.2 \%)^{30}$ and adjusted market risk premium (4-4.5\%). The latter is calculated as beta in the industry $\left(0.77-0.90^{31}\right)$ multiplied by the market risk premium (at least $5 \%,{ }^{32}$ although it could be higher considering legal uncertainty). As there is no expected growth in income in the compulsory lease relations, the cap rate should be at least at the amount of discount rate, i. e. 4.8-7\%. Discount rate calculation does not include the fixed expenses like real estate tax, thus cap rate as per formula (3) is at least $6.3 \%$.

In free market, an optimal payback period on investment in real estate is between 7 and 30 years (cap rate $4-12 \%$ ). ${ }^{33}$ Long payback periods (low cap rates) are acceptable only if the income is stable, predictable and easy to collect, none of which is currently applicable to the compulsory land lease. For the land owner to receive a net income of at least $3.5-5 \%$ of the value of the property in a year, the lease fee in amount of $6 \%$ is not sufficient (see Table 1) ${ }^{34}$ However, optimal net income (see results as per formula (2) and (3)) must be at least $6.2 \%$ of the property value. It is possible only if

27 Dzīvojamo māju pārvaldīšanas likums: LV Likums. [Law On Administration of Residential Houses]. Latvijas Vēstnesis, 2009. 19. jūnijs, Nr. 96 (4082), Sec. 17.3 (6), 14. (4.3).

28 The Regulatory Authority prepares the methodology to calculate the prices for public utilities in the regulated sectors to ensure the public receives continuous, safe and qualitative public utilities whose tariffs (prices) conform to economically substantiated costs.

29 Kapitāla atdeves likmes aprēkināšanas metodika: Sabiedrisko pakalpojumu regulēšanas komisijas padomes lēmums Nr. 1/23. [Methodology for calculating the rate of return on capital: decision No. 1/23 of Public Utilities Commission]. Latvijas Vēstnesis, 2018. 15. augusts, Nr. 161 (6247).

30 See supra note 26.

31 Unlevered beta for real estate investments in Latvia, small companies. See: WaccExpert. Data for Latvia, real estate sector. Available at: http://www.waccexpert.com/?country=1730\&sector= 147\&detailledView=true [last viewed April 17, 2019].

32 Kapitāla atdeves likmes aprēḳināšanas metodika: Sabiedrisko pakalpojumu regulēšanas komisijas padomes lēmums Nr. 1/23. [Methodology for calculating the rate of return on capital: decision No. 1/23 of Public Utilities Commission]. Latvijas Vēstnesis, 2018. 15. augusts, Nr. 161 (6247), Sec. 11.

33 Judgement of 27 January 2011 by the Constitutional Court of the Republic of Latvia in case No. 2010-22-01, para. 13.4.

${ }^{34}$ Note: The lease amount does not include Value Added Tax as according to this tax the taxable amount is the lease Senate has delivered a judgement in case No. SKC-42/2019 saying that the VAT should be included in the price,thus the lease amount to reach the criteria of fair compensation should be $21 \%$ higher. 
the lease fee is above $10 \%$ of the cadastral value. If the lease fee amount set in the law is lower, the landowner does not receive a fair compensation.

\section{Impact of the income on the value of the property}

The lease amount, when reviewed from a political or legal aspect, is not attributed to the value of the land. However, the economic aspect of the compulsory land lease reveals that the lease fee amount directly affects the value of the property. There are three property valuation methods for real estate: the income approach, the sales comparison approach and the cost approach. In case of separated ownership, the value of the land is determined mainly by its profitability. If the income is low and unpredictable, properties lose their value.

The cadastral value of the property depends on the cadastral value in the particular zoning, but the latter depends on the real estate market information. ${ }^{35}$ With a low market value, over a longer period of time inevitable is the decline in the cadastral value, resulting in a corresponding reduction in the income and, again, as in a downward spiral, a reduction in the market value of the property.

\section{Conclusions}

The optimal lease fee amount determined under each of the methods: political, legal and economical, gives results so dramatically different that it is impossible to reach a common denominator. Politically a lease fee amount around 3-4 \% of cadastral value is preferred as this is the amount apartment owners are willing to pay. Legal considerations state that the lease fee amount should be at least $6 \%$ of the cadastral value not to infringe the constitutional rights to the property of the landowners. Economical calculations show that for a property not to lose its value and give a fair return the lease fee amount should be over $10 \%$ of the cadastral value per year.

In this situation a duty of a socially responsible state is to find a solution where the protection of apartment owners does not happen at the expense of landowners. In the opinion of the author, it is the duty of the state to find a solution to offer a buy-out option for landowners. Then it would be their choice: either to sell the land to the state, or the apartment owners, or a fund created by the state, ${ }^{36}$ where the price is set at the property's current value, or to continue leasing the land for the reduced fee set in the law, thus risking their property would gradually lose its value. Unacceptable is the current situation where a subtle expropriation happens under an illusion of guaranteeing a "reasonable" income from the property.

35 Nekustamā īpašuma valsts kadastra likums: LV Likums. [National Real Estate Cadastre Law]. Latvijas Vēstnesis, 2005. 22. decembris, Nr. 205 (3363), Sec. 69.

36 Note: On 11.03.2019. a public discussion in possible models for unifying the separated ownership was held in Saeima. Information and presentations available: http://saeima.lv/lv/aktualitates/saeimaszinas/27738-diskusija-saeima-parruna-dalita-ipasuma-izbeigsanas-problematiku. 


\section{BIBLIOGRAPHY}

\section{Literature}

1. Bethell A. Capitalization Rate Formula \& What a Good Cap Rate Is. Available at: https:// fitsmallbusiness.com/capitalization-rate-formula/ [last viewed April 17, 2019].

2. Brueggeman W. B., Fisher J. D. Real estate finance and investments. $10^{\text {th }}$ ed. New York: McGrawHill Irwin, 1997.

3. Latvijas Republikas Saeimas Juridiskais birojs. [Legal Bureau of the Saeima of the Republic of Latvia]. Opinion on a draft law Nr. 446/Lp12. Available at: http://titania.saeima.lv/LIVS12/ SaeimaLIVS12.nsf/0/F5DA04880A59C96DC2258128004D50E1 [last viewed August 16, 2019].

4. Latvijas Republikas 12. Saeimas deputāts A. Elksniņš. Proposals to the draft law "Grozijumi likumā "Par valsts un pašvaldību dzīvojamo māju privatizāciju” (446/Lp12). [Member of the $12^{\text {th }}$ Saeima of the Republic of Latvia A. Elksniņš. Proposals to the draft law "Amendments to the law "On Privatisation of State and Local Government Residential Houses" (446/Lp12).] Available at: http://titania.saeima.lv/LIVS12/SaeimaLIVS12.nsf/0/11A87AA271C6FF49C2257F9B0044CE84? [last viewed August 16, 2019].

5. Saeimas Valsts pārvaldes un pašvaldības komisija. Anotation to the draft law "Piespiedu dalitā īpašuma privatizētajās daudzdzīvokḷu mājās izbeigšanas likums” (Nr. 1211/Lp12). [Public Administration and Local Government Committee of the Saeima of the Republic of Latvia, annotation to the draft law "Law on Terminating the Enforced Separated Ownership in the Privatised Multi-apartment Buildings" (No. 1211/Lp12)]. Available at: http://titania.saeima.lv/ LIVS12/saeimalivs12.nsf/0/5986C97B49BD24A3C225826D004B1314 [last viewed July 30, 2019].

\section{Normative acts}

6. Dzīvojamo māju pārvaldīšanas likums: LV Likums. [Law On Administration of Residential Houses]. Latvijas Vēstnesis, 2009. 19. jūnijs, Nr. 96 (4082).

7. Kapitāla atdeves likmes aprēķināšanas metodika: Sabiedrisko pakalpojumu regulēšanas komisijas padomes lēmums Nr. 1/23. [Methodology for calculating the rate of return on capital: decision No. 1/23 of Public Utilities Commission]. Latvijas Vēstnesis, 2018. 15. augusts, Nr. 161 (6247).

8. Nekustamā īpašuma valsts kadastra likums: LV Likums. [National Real Estate Cadastre Law]. Latvijas Vēstnesis, 2005. 22. decembris, Nr. 205 (3363).

9. Par zemes nomas maksas maksimālo lielumu Latvijas Republikas pilsētās: Ministru Padomes lemmums Nr. 243. [Decision No 243 of the Council of Ministers "On the maximal amount of the lease fee in the cities of the Republic of Latvia]. Latvijas Vēstnesis, 1993. 15. maijs, Nr. 25.

10. Par zemes reformu Latvijas Republikas pilsētās: LV Likums [Law “On Land Reform in Cities of the Republic of Latvia”]. Ziņotājs, 1991. 19. decembris, Nr. 49/50.

\section{Court practice}

11. Judgement of 9 April 2019 by the Senate of the Republic of Latvia in case No. SKC-42/2019.

12. On compliance of Section 1 of the law "Amendments to the Law on Privatisation of State and Local Government Residential Houses" adopted on 1 June 2017, and of the law "Amendments to the Law on Land Reform in the Cities of the Republic of Latvia" adopted on 22 June 2017, with Articles 1 and 105 of the Constitution of the Republic of Latvia. Judgement of 12 April 
2018 by the Constitutional Court of the Republic of Latvia in Case No. 2017-17-01. Latvijas Vēstnesis, 2018. 13 aprīlis, 2018. 74 (6160).

13. On Compliance of the Words "Apartment Houses" of Section 12(2) of Law On Land Reform in the Cities of the Republic of Latvia and Para 7 of the Transitional Provisions Thereof, and the First Sentence of Section 54(2) of Law On Privatization of State and Local Government Apartment House", and Para 40 of the Transitional Provisions Thereof with Article 1 and Article 105 of the Satversme of the Republic of Latvia: Judgement of 15 April 2009 by the Constitutional Court of the Republic of Latvia in Case No. 2008-36-01. Latvijas Vēstnesis, 2009. 21. aprīlis, Nr. 60 (4046). Available at: http://www.satv.tiesa.gov.lv/web/viewer.html?file=/wp-content/ uploads/2008/09/2008-36-01_Spriedums_ENG.pdf [last viewed June 18, 2019].

14. On Compliance of Para 7 of Transitional Provisions of Law On Land Reform in the Cities of the Republic of Latvia, Insofar it Applies to Land under Residential Apartment Houses and Para 40 of Transitional Provisions of Law On Privatization of State and Local Government Residential Houses with Article 1 and Article 105 of the Satversme of the Republic of Latvia: Judgement of 27 January 2011 by the Constitutional Court of the Republic of Latvia in Case No. 2010-22-01. Latvijas Vēstnesis, 2011. 1. februāris, Nr. 17 (4415). Available at: http://www.satv.tiesa.gov.lv/ web/viewer.html?file=/wp-content/uploads/2010/03/2010-22-01_Spriedums_ENG-1.pdf [last viewed June 18, 2019].

\section{Internet sources}

15. Damoran A. Country Default Spreads and Risk Premiums. Available at: http://pages.stern.nyu. edu/ adamodar/New_Home_Page/datafile/ctryprem.html [last viewed April 17, 2019].

16. European Central Bank. Long-term interest rate statistics for EU Member States. Available at: https://www.ecb.europa.eu/stats/financial_markets_and_interest_rates/long_term_interest_rates/html/index.en.html [last viewed April 17, 2019].

17. WaccExpert. Data for Latvia, real estate sector. Available at: http://www.waccexpert.com/ ?country $=1730 \&$ sector $=147 \&$ detailledView $=$ true [last viewed April 17, 2019]. 